\title{
PROBLEMS OF NOMADIC GOAT BREEDERS AND THEIR EFFECTS ON FOREST
}

\author{
Eyyüp KARAGÖL \\ Forest General Directorate, Şanlıurfa Forest Management Directorate, Turkey, ekaragol63@gmail.com \\ (iD) https://orcid.org/0000-0001-9749-2651 \\ Mahmut KESKIN*
}

Mustafa Kemal University, Agriculture Faculty, Department of Animal Sciences, Turkey, mkeskin@mku.edu.tr (iD) https://orcid.org/0000-0002-8147-2477

Received: 10.10.2017, Accepted: 16.05.2018

*Corresponding author

Case Studies

\begin{abstract}
This study was carried out to evaluate the relationship between goat breeders and forests with the perspectives of breeders and forestry officers and to develop some solution proposals on the issues expressed as problems. The material of the study was the forest guard officers and forestry technicians who are the personnel of the Sanliurfa-Mardin-Diyarbakir Forestry Directorates and the families of the nomadic people who stayed in Karacadağ and Karacurun areas in the province of Viranșehir in Şanliurfa. At least half of the nomadic families, the number of which is 19, in the area and all personnel working in the Forestry Management Department were surveyed. The results showed that 57.9\% of the goat breeders were illiterate or primary school graduates, $52.6 \%$ and $100.0 \%$ of them preferred Zom sheep and hair goat, respectively and all of them did not give any additional feed to the animals except the winter season. At the end of the study it was reported that when the goat was grazed uncontrollably it could be harmful to the areas where young trees were found but it would be beneficial to the forest when grazing in areas with large trees.
\end{abstract}

Keywords: Hair goat, afforestation, education, milk products, nomads

\section{GÖÇER KEÇİ YETIŞTİRICILERINIIN SORUNLARI VE ORMAN ÜZERINE OLAN ETKÍLERİ}

$\ddot{0} \mathbf{z}$

Bu çalışma, keçi yetiştiricileri ile orman ilişsilerini yetiştirici ve orman görevlilerinin bakış açıları ile değerlendirmek ve sorun olarak ifade edilen konularda çözüm önerileri geliştirmek amacıyla yürütülmüştür. Çalışmanın materyali, Şanlıurfa'nın Viranşehir ilçesinde Karacadağ ve Karacurun bölgelerinde kalan göçebe aileleri ve Şanlıurfa-MardinDiyarbakır Orman Müdürlüklerinde görevli teknisyenler ve orman muhafaza memurları olmuştur. Bölgedeki göçebe ailelerin en az yarısı olan 19 aile ile ve Orman İșletme Müdürlüğü'nde çalıșan tüm personel ile anketler yapılmıștır. Elde edilen sonuçlar keçi yetiştiricilerinin \%57.9'unun okuma yazma bilmediğini veya ilkokul mezunu olduklarını, tamamının Kıl keçi tercih ettiğini \%52.6'sının Zom koyunu yetiştirdiğini ve tamamının hayvanlarına kış mevsimi dışında meraya ek olarak yem vermediklerini göstermiştir. Çalışmanın sonunda, keçinin kontrolsüz olarak otlatılması durumunda genç ağaçların bulunduğu alanlarda zararlı olabileceği, ancak büyük ağaçların olduğu alanlarda otlatıldığında ormana faydalı olacă̆ı bildirilmiştir.

Anahtar Kelimeler: Kıl keçisi, ağaçlandırma, eğitim, süt ürünleri, göçerler

Cite

Karagöl, E., Keskin, M., (2018). “Problems of Nomadic Goat Breeders and Their Effects on Forest”, Mugla Journal of Science and Technology, 4(1), 11-15.

\section{Introduction}

In Turkey, particularly in the 1990s, goat breeding in and around the forest villages has been much debated, different policies were developed to protect the forests from "goat damage" without paying enough attention to the social and cultural dimensions of the subject and the number of goats decreased considerably [1].

However, goat has been the most increasing ruminant animal species in the World in the last 30 years. In this period, it is observed that the number of goats in Turkey, which was around 19 million heads in 1980, decreased continuously and declined to 5.1 million heads in 2009 . In parallel with the social consciousness in recent years, the number of goats increased again due to the increase in demand to goat products and government incentives, and reached 10.3 million heads in 2016 (www.tuik.gov.tr).

Goat breeding in Turkey is based on Hair goat with proportion of $97 \%$ and generally performed extensively. Geographic and ecologic conditions are suitable for goat raising as well as socioeconomic circumstances of the goat keepers. Feeding of the goats is generally carried out at the pastures in or around forests. Goat farming continued to exist as a dominant animal production branch in and around the forest villages even in periods when the goat grazing in the forest was prohibited. Although the goat has vital importance for these villagers, the 
first solution that came to mind by some authorities for the protection of forests was put forward as the removal of Hair goats from the forest or slaughtering of them. In this direction, economic, social, administrative and technical applications have been made and are being done.

Whereas it is not the goat that is harming the forest, the person who is responsible for the maintenance and management of the goat damages the forest [2]. It is easy to see the importance of human influence in the destruction of forest areas in the 21st century when industrialization, urbanization and infrastructural work are widespread. Despite the forest and goat being the parts of the ecosystem have lived together for thousands of years, the absence of a goat-related remarkable destruction in terms of forest indicates that the goat is not a forest-damaging animal expressed by many people. Even today, the benefits of goats for the forest have been discussed [1].

When goats are grazed uncontrollably, they can eat new shoots of the trees and harm the forest. Sometimes insect damage can increase in trees due to the eaten of tree bark. For this reason, goat grazing on afforestation, soil conservation and rehabilitation areas in the forest is prohibited by general directorate of forestry. The solution is not to ban goat grazing in the forest, but to educate the person managing it. It should not be forgotten that in-forest goat breeding is an indispensable cultural asset especially for the nomads named yörük [3].

The aim of this study is to evaluate the relationship between goat breeders and forests with the perspectives of breeders and forestry officers and to develop some solution proposals on the issues expressed as problems.

\section{Materials and methods}

The material of the study was the forest guard officers and forestry technicians who are the personnel of the Sanliurfa-
Mardin-Diyarbakır Forestry Directorates and the families of the nomadic people who stayed in Karacadağ and Karacurun areas in the province of Viranșehir in Şanlıurfa. At least half of the nomadic families, the number of which is 19 , in the area and all personnel working in the Forestry Management Department were surveyed. The minimum and maximum duty periods in the department of the interviewed personnel are 4 years and 30 years, respectively. For the questionnaires, sample size was determined by using the bias sampling method [4]. In the questionnaire, questions were asked to determine the relationship between forest and goat breeders in the region, the areas where the nomadic people stay in winter and summer in economic order based on nomadic animal husbandry, migration routes, the dwellings they used, the products they obtained and how they marketed them, the highlands activities they carried out, the problems they faced and the expectations from the state. The opinions of the personnel of Forestry Management Office were also taken to see and evaluate the issue with the perspective of forest workers. The obtained data were analysed by frequency analysis with SPSS packet program [5].

\section{Results}

The educational status, residence places in winter, income levels and marital status of the nomadic breeders in the study area are given in Table 1. Educational levels of nomadic breeders are generally insufficient, monthly incomes are generally less than $1000 \mathrm{TL}$ and all of the nomadic breeders were married.

Table 1. General information about nomads

\begin{tabular}{|c|c|c|c|c|c|c|c|}
\hline Educational status & $\%$ & $\begin{array}{l}\text { Residence } \\
\text { places }\end{array}$ & $\%$ & Income level & $\%$ & $\begin{array}{l}\text { Marital } \\
\text { status }\end{array}$ & $\%$ \\
\hline Secondary school & 42.1 & Siverek & 21.1 & $<500 \mathrm{TL}$ & 15.8 & Married & 100.0 \\
\hline Primary school & 42.1 & Viranșehir & 26.3 & $500-1000 \mathrm{TL}$ & 42.1 & & \\
\hline \multirow[t]{3}{*}{ İlliterate } & 15.8 & Mardin & 26.3 & $>1000 \mathrm{TL}$ & 10.5 & & \\
\hline & & Diyarbakır & 21.1 & No specify & 31.6 & & \\
\hline & & Hilvan & 05.2 & & & & \\
\hline
\end{tabular}

Some structural characteristics of animal production are given in Table 2. All nomadic breeders prefer Hair goat as goat breeds. These people usually prefer to grow Zom sheep and use tractors during migration. It was also found that the nomadic livestock breeding was made entirely in the pasture in spring, summer and autumn period.

Table 2. Structure of animal production

\begin{tabular}{lcc}
\hline Vehicle for migration & $\mathrm{n}$ & $\%$ \\
\hline On foot with animal & 1 & 05.3 \\
Tractor & 18 & 94.7 \\
\hline Preferred goat breed & $\mathrm{n}$ & $\%$ \\
\hline Hair goat & 19 & 100.0 \\
\hline Preferred sheep breed & $\mathrm{n}$ & $\%$ \\
\hline Zom & 10 & 52.6 \\
Awassi & 1 & 05.3 \\
Zom and Awassi & 3 & 15.8 \\
Zom and Morkaraman & 2 & 10.5 \\
Boz and Suruç & 1 & 05.3 \\
No prefer sheep & 2 & 10.5 \\
\hline Animal feeding & $\mathrm{n}$ & $\%$ \\
\hline Pasture in spring, summer and fall, & & \\
pan in winter & 19 & 100.0 \\
\hline
\end{tabular}

\section{Discussion}

\subsection{Nomadic people}

The region's nomads migrate with the aim of benefiting from pasture in or around forest within the family structure. This seems to be consistent with the definitions and reports made by Kutlu [6]. An important problem of Turkish goat breeding is that the levels of education of the breeders are insufficient. Some of the breeders were not literate, even those with the highest level of education were detected as secondary school graduates. This level of education is similar to the examples of goat breeders in different regions of Turkey [7-11]. This low level of education is an important handicap for goat breeding studies. One reason for the low educational status of nomads is the schedule of education and training that does not match their lifestyles. The nomads, who started to come to Karacadağ in March, remain in the region until the start of snowfall (November-December). Therefore, children can go to school for 4-5 months. The solution to this problem can be provided by opening the summer school in the highland area, by means of a transportable education system that students move to the school or mobile teaching system that teachers move to the highland. Monthly incomes of nomads migrating from different 
settlements to Karacadağ region were generally below $1000 \mathrm{TL}$ (approximately 285 USD).

As seen Table 2, most nomadic breeders migrated with tractors. Only one breeder completed the route on foot along with the animals. All breeders preferred Hair goat to raise that were doing extensive production during summer. They offered additional concentrate and wheat or lentil straw in winter months. The nomadic breeders stated that Hair goat was the most suitable breed for the locality in terms of durability, the meat yield was also good and therefore they preferred Hair goat. Although Hair goat does not have high milk and fertility rate, it is a goat breed that cannot be given up for nomads in terms of hard hoof structure and resistance to hot and cold environmental conditions $[12,13]$ when compared to high yield goat breeds.

Zom sheep was the most preferred sheep breed by nomadic breeders. While the proportion of Zom sheep breeders was $52.6 \%$ and that of Awassi sheep breeders was 5.3\%, it was observed that different breeds were present together in other flocks. Koncagül et al $[14,15]$ stated that the breeding of Zom sheep in the Karacadag region was done and this breed morphologically resembled Karakas, Awassi and Akkaraman sheep. The breeders expressed that they provided the highest yields of meat and milk from this breed in their own conditions and that's why they preferred this breed. The reports show that both Zom and Awassi sheep breeds are in a level that can be considered as good in terms of milk yields and fattening performances among Turkish sheep breeds [16-19].

Male animals were grown up to 9-12 months of age and then either fattened or sold directly. The milk produced from female animals was usually processed as cheese. The cheese yield is expressed as $4 \mathrm{~kg}$ milk for $1 \mathrm{~kg}$ cheese by the breeders. This may be due to the fact that the more intensive sheep's milk may increase the cheese yield with the result that sheep and goat pastures coexisted [20]. It may also have been influenced by the fact that milk yield is low in Hair goat only fed by pasture and therefore the content of dry matter is high.

After the cheeses were made by the nomadic families with traditional methods, they were kept either in cold storage depots $(78.9 \%)$ or in wells or caves (21.1\%). Storing and selling after processing of milk to cheese are among the general practices of nomadic breeders. Some researchers also reported that nomads generally evaluate the milk as cheese [21-23]. As stated by Emiroğlu [24], meat (fattening material) and milk or cheese produced by immigrants cannot be consumed only by the nomadic family and the excess of the family needs are sold. All of the breeders have expressed that there is no problem in marketing the products they produce.

Animal diseases which were common in Karacadağ region were detected as smallpox, bronchitis, diarrhea, brucella, foot and mouth diseases and enterotoxemia. These diseases are similar to the diseases reported in different studies conducted in different regions of Turkey [25, 26]. All of the breeders reported that their animals were vaccinated against these diseases. Despite the vaccination of animals, $47.4 \%$ of the breeders stated that these diseases could occur and they treated them with medicines. Different researchers stated that parasite control and protective vaccine applications were made by many breeders in Turkey $[8,21,22,25,27]$.

The importance of nomadic animal breeding in Turkish animal production sector is gradually decreasing as a consequence of the increase of urbanization, industrialization and the intensification of agriculture. In this declining trend, other problems encountered by the nomads are also affected. The problems most expressed in the current study were transportation, water supply, accommodation and electricity. It was also stated that the access of the nomads to the accommodation places was long and they had to pass through very bad roads since some of the migration roads remained in the forest and it was forbidden to pass through the forest. There were problems in watering the animals with the reason that the forest entrance was blocked and the water wells were kept in the forest. The nomadic people who said they met their electricity needs in their own panels have specified that it was expensive and that they were waiting for support from the government in this regard. The nomads living in a tent made of goat hair generally required mobile health services to the problems such as snaking, scorpion sting, bathroom and toilet problems. They also wanted to make their roads more useful for transportation to the hospital in urgent health problem and containers for accommodation. These and similar problems are leading to a gradual decline of the nomadic life system, which has a cultural past in Turkey.

The education of the children was not considered as a problem by nomads whose education levels were also generally inadequate. However, the fact that the immigrants are away from the actual settlement areas for 9 months, causes serious problems for the children in the school age in terms of continuity to the schools.

$63.2 \%$ of nomadic goat breeders in the study thought that goat did not harm the forest. Aside from harm, these breeders believed that when the goat was grazed in the forest, the risk of fire was reduced, the fertilizer was beneficial to the forest soil and resting in the shade of the forest under the sun at $45-50{ }^{\circ} \mathrm{C}$ temperature was beneficial for the productivity and development of the animals. On the other hand, we know that the problems between nomadic livestock and forestry reveals when nomadic livestock, especially Hair goats enter forest areas by necessity [3]. Nomadic breeders who stated that they did not knowingly damage the forest expressed that freelivestock animals could damage the young trees by entering the afforestation areas because of the broken wires and the doors around the forests and that this problem could be eliminated with protective measures.

The policy of allocating pasture lands to the forest with the change of qualifications by the General Directorate of Forestry was not welcomed by nomads in the study areas. According to the breeder, the main problem was not the desire for forests in the region, but the way of working by covering and banning large areas with barbed wire. The prohibition of forest areas by turning them with wire fences causes an increase in grass density in the forest. This increment not only increases the risk of fire but also encourages the animals to enter the forest since there is no pasture rehabilitation work in the region.

Arrangement of about fifty crime documents by forest guard officers in the last two years showed that the problem of grazing in the forest is not diminished. The prohibition of animal grazing outside the regeneration areas in the forest was also perceived as confrontation between the breeder and the state. In general, the nomads who indicate that they love the forest, the tree and nature, oppose the conversion of pastureland into forest. However, they are reacting to prohibition of entry by making afforestation work in very large areas. They think that livestocking in forest areas where large trees exist is beneficial to both the forest and the animals.

The nomadic breeders who said that even a square meter of soil was very important, they stated that they support the study of small areas rather than the closure of large lands. The afforestation work should not be carried out in very wide pastures. If, instead of this method, gradual afforestation is carried out in smaller parcels, nomads will be less affected negatively. 


\subsection{Personnel of forestry management department}

For sustainable animal production in nomadic system, efforts should be made for developing this production system instead of eliminating it [28]. According to the personnel of the General Directorate of Forestry, the main cause of the damages that given to the forest by nomads was to allocate the pastures to the forest and to plant the forestation works in full area including these areas. It is said that the people of the region were aware of the benefits of forests and that they did not oppose the forestry work, but when the forestation work was carried out in large areas, the forest was not beneficial to them but harmful. For this reason, problems arise between the nomads and forest officials. Nomadic people can cause direct or indirect damage to forests due to the perception taken from the hands of the pastures. The animal breeders who oppose the conversion of the pastures into the forest graze the animals by damaging the wire fences or breaking the access doors to the forest especially at night. Therefore, reforestation, rehabilitation and regeneration areas are directly damaged by animals. Forest officers stated that criminal records were set for animal breeders who were caught red-handed during nighttime conservation activities but even this is not deterrence, and sometimes more damage is caused.

According to the employees of the General Directorate of Forestry, the change of the afforestation policy should be brought to the agenda. Thus, if work is done in smaller parcels in places covered by afforestation instead of working in the area entirely, it will contribute to the elimination of social problems and will increase the success rates in afforestation activities.

The protection of forest lands is usually done by providing employment from villagers around the site. The election of these wardens depends on the initiative of the concerned headmen. It is therefore impossible for anyone other than the people of the village to work. But if it is thought that the damage to the forest is usually at night and that the wardens are only working during the day, it should be judged that it would be beneficial to increase the employment opportunities and to give the night guard jobs to the nomadic families. Even though the night protection works are done by Forest Guard Officers, it is not enough and it is seen from the given damage.

Water wells in the forest make it necessary for the immigrants to enter the forest. The water can be transferred from these wells by pipes or hoses. Moreover, making wire fence along the access roads to the animals well controlled manner may be provided access to water.

For the solution of the road network problems of the nomads, the maintenance of the roads can be carried out by the Forestry Organization within the scope of the annual routine road maintenance works on the forest lands.

With the aim of solving the problems of nomads and raising the standards of living, the FOR-MIGR (forest-migration) project can be implemented to provide credit support to animal breeders migrating around the forest.

According to the employees of the General Directorate of Forestry, it is imperative that at least 5 years of afforestation areas are prohibited for all kinds of livestock. On the other hand, in forests where grown trees are present, controlled grazing reduces the risk of fire to minimum level. As a matter of fact, there are significant differences in the incidence of fires among non-grazing and controlled grazing areas.

The animals benefit the insect feeding with manure during the grazing in the forest. In addition, fertilization of the soil by the animals has a positive effect on the germination and plant growth, that is, it is beneficial to the ecosystem. In the forests where the crowded oak or maize plants are found, the pathways that the nomads make are contributing to the forest workers' ability to travel freely in the forest. Pathways made by nomads in forests where the crowded oak trees or maquis plants are also contributing to the forest workers' ability to travel freely in the forest. Keskin et al. [1] and Gültekin [29] informed that it would be beneficial to have goat grazing in forest areas where trees were grown in terms of forest fires prevention and ecological cycle.

As result, the goats will damage the forest when uncontrolled grazing. Encouraging grazing in the forest areas where the trees are grown will contribute to the sustainability of nomadic goat and sheep breeding and will also provide benefits to forests such as reducing forest fire risk and fertilizing.

\section{References}

[1]. Keskin, M., Gül, S., Karagöl, E., Türkiye'de keçi-orman ilișkisi. 9. Ulusal Zootekni Bilim Kongresi. Konya, Turkey, 2015.

[2]. Kaymakçı, M., Taşkın, T., Türkiye'de Orman-Kıl Keçi İlişkilerinin Düzenlenmesinde Keçi Islah Çalışmaları. Proceeding of The XI. World Foresty Congress, Antalya, Turkey, 1997

[3]. Alkan, H., Uygur, T., Views of HairGoat Breeders Concerning Nomadic Livestock Breeding and Forestry:An Example from the Turkey. Int. J. Environ. Res., 9, 969-976, Summer 2015.

[4]. Çiçek, A., Erkan, O., Tarım Ekonomisinde Araştırma ve Örnekleme Yöntemleri, Gazi Osman Paşa Üniversitesi Ziraat Fakültesi Yayınları, No: 22, Tokat, 1996.

[5]. Kinneer, P.R., Gray, C.D., SPSS for Windows. Department of Psychology, University of Aberdeen. UK, 1994.

[6]. Kutlu, M., Şavaklı Türkmenlerde Göçer Hayvancılık. Kültür ve Turizm Bakanlığı Milli Folklor Araștırma Dairesi Yayınları: 84, Gelenek-Görenek ve İnançlar Dizisi: 4, Ankara, Turkey, 1987.

[7]. Soysa,l M.İ., Kök, S., Gürcan, K.E., Özdüven, L.M., Edirne ili keçiciliği üzerine bir araştırma. Süleyman Demirel Üniversitesi Ziraat Fakültesi Dergisi, 3, 24-31, 2005.

[8]. Bilginturan, S., Burdur ili damızlı koyun ve keçi yetiştiriciler birliği üyesi işletmelerin yapısal özellikleri ve sorunları üzerine bir araștırma, Yüksek lisans tezi, Süleyman Demirel Üniversitesi, Isparta, Turkey, 2008.

[9]. Acar, M., Isparta ili damızlık koyun keçi yetiştiricileri birliği üyesi keçicilik işletmelerinin mevcut durumu ve teknik sorunları üzerine bir araștırma, Yüksek lisans tezi, Süleyman Demirel Üniversitesi, Isparta, Turkey, 2010.

[10]. Elmaz, Ö., Ağaoğlu, Ö.K., Akbaş, A.A., Saatçi, M., Çolak, M., Metin, M.Ö., The current situation of small ruminant enterprises of Burdur province. Eurasian Journal of Veterinary Science, 30, 95-101, 2014.

[11]. Tüfekçi, H., Olfaz, M., Kastamonu ili küçükbaş hayvan yetiştiriciliğinin sorunları ve çözüm önerileri. Türk Tarım Gıda Bilim ve Teknoloji Dergisi, 3, 577-582, 2015.

[12]. Özcan, L., Küçükbaş Hayvan Yetiştirme I (Keçi Üretimi). Çukurova Üniversitesi Ziraat Fakültesi Ders Kitabı, Adana, Turkey 1989.

[13]. Şengonca, M., Koşum, N., Koyun ve keçi yetiştirme (Keçi yetiştirme ve islahı). Ege Üniversitesi Ziraat Fakültesi Yayınları İzmir, Turkey, 2015.

[14]. Koncagül, S., Akça, N., Vural, M.E., Karataș, A., Bingöl, M., Zom koyunlarının morfolojik özellikleri. Kafkas Üniversitesi Veteriner Fakültesi Dergisi, 18, 829-837, 2012.

[15]. Koncagül, S., Karataş, A., Vural, M.E., Akça, N., Bingöl, M., Factors affecting lactation milk yield and some lactation characteristics of Zom sheep in farmer conditions. I Ig dır University J Inst Sci \& Tech, 2, 87-93, 2012. 
[16]. Biçer, O., İvesi koyunlarında besi gücü ve karkas özellikleri üzerinde bir araștırma, Doktora tezi, Çukurova Üniversitesi, Adana, Turkey, 1988.

[17]. Esenbuğa, N., Süt protein tipleri ile koyunların laktasyon özellikleri ve kuzuları büyüme karakteristikleri arasındaki ilişsiler, Yüksek lisans tezi, Atatürk Üniversitesi, Erzurum, Turkey, 1995.

[18]. Macit, M., Aksoy, A., Atatürk üniversitesi tarım işletmesinde yetiştirilen İvesi ve Morkaraman kuzuların yarı entansif şartlarda besi performansları bakımından karşılaştırılması. Atatürk Üniversitesi Ziraat Fakültesi Dergisi, 28, 454-463, 1997.

[19]. Gündüz, Z., Kilis koşullarında geleneksel koyun yetiştiriciliği sistemi içerisinde farklı dönemlerde doğan Ivesi erkek ve dişi kuzuların gelişme ve besi performansı, Yüksek lisans tezi, Mustafa Kemal Üniversitesi, Hatay, Turkey, 2014.

[20]. Çelik, Ş., Uysal, Ş., Beyaz peynirin bileşim, kalite, mikroflora ve olgunlaşması. Atatürk Üniversitesi Ziraat Fakültesi Dergisi, 40, 141-151, 2009.

[21]. Dellal, İ., Keskin, G., Dellal, G., GAP bölgesinde küçükbaş hayvan yetiștiren işletmelerin ekonomik analizi ve hayvansal ürünlerin pazara arzı. TEAE, Yayın No:83, Ankara, Turkey, 2002.

[22]. Koyuncu, M., Uzun, Ş.K., Tuncel, E., Güney Marmara Bölgesi keçicilik işletmelerinin genel durumu ve verim özelliklerinin belirlenmesi üzerine araștırmalar II. işletmelerin üretim potansiyelleri ve sorunları. Ankara üniversitesi Ziraat Fakültesi Tarım Bilimleri Dergisi, 12, 29-36, 2006.

[23]. Sezgin, Y., Bitlis ilinde göçer ailelerin küçükbaş hayvancılık faaliyetleri, Yüksek lisans tezi, Yüzüncü Yıl Üniversitesi Van, Turkey, 2006.

[24]. Emiroğlu, M., Bolu'da yaylalar ve yaylacılı, Ankara Üniversitesi DTCF Yayınları, No: 272, Ankara Üniversitesi Basımevi, Ankara, Turkey, 1977.

[25]. Aksoy, A., Yavuz, F., Hayvancılık işletmelerinin Avrupa Birliğine uyumu ve rekabet edebilirliği: Doğu Anadolu örneği. Tarım Ekonomisi Dergisi, 14, 37-45, 2008.

[26]. Karakuş, F., Akyol, S., Van ili küçükbaş hayvan işletmelerinin mevcut durumu ve verimliliği etkileyen sorunların tespiti üzerine bir araştırma. Yüzüncü Yıl Üniversitesi Fen Bilimleri Enstitüsü Dergisi, 18, 9-16, 2013.

[27]. Tölü, C., Daş, G., Yurdabak, S., Uğur, F,. Konyall, A., Savaş, T., Aktürk, D., Turkan, H., Türkiye'nin önemli hayvancıllk bölgelerinden Biga koyunculuğuna genel bir bakış. $V$. Zootekni Bilim Kongresi, Van, Turkey, 2007.

[28]. Tolunay, A., Ayhan, V.,Hair Goat Breeding in Turkey in the Present Situation in Utilization of Forest Resources, Bottlenecks and Solutions. Goat Keeping National Congress, pp, 92-97, Canakkale, Turkey, 2010

[29]. Gültekin, H.C., Keçiler ve keçi çobanları. www.plantdergisi.com/yazi-hazincemal-gultekinkeciler-ve-keci-cobanlari--61.html. Connection date: 02.09.2014. 